\title{
Efficacy of Hydrophilic Polymer on Sunflower (Helianthus annus L.) Production in Spring
}

\author{
Vikram Bharati ${ }^{1}$, S. Kiran Kumar $^{1} *$ and S.S. Prasad ${ }^{2}$ \\ ${ }^{1}$ Department of Agronomy, ${ }^{2}$ Department of Soil science, T.C.A. Dholi, Muzaffarpur-843 121 \\ Dr. Rajendra Prasad Central Agricultural University, Pusa, \\ Samastipur (Bihar) 848 125, India \\ *Corresponding author
}

\begin{abstract}
A B S T R A C T
An experiment was carried out at research farm at T.C.A. Dholi, Muzaffarpur (Bihar)

Keywords

Hydrophilic polymer,

Sunflower,

Vermicompost, Soil

moisture

\section{Article Info}

Accepted:

15 April 2019

Available Online:

10 May 2019

during Spring season of 2016-17, to study the efficacy of hydrophilic polymer on sunflower production. The experiment was laid out in randomized block design with 3 replications. The experiment was comprised of a total of 7 hydrophilic combinations,. Sunflower hybrid KBSH-44 was used and among the hydrophilic substrates hydrogel and humic acid were applied @2.5kg/ha, while vermi compost@2.5t/ha and fly ash @ $2.0 \mathrm{t} / \mathrm{h}$. Irrigation was provided based on calculation of available soil moisture. The results emphasized that application of FYM, hydrogel, vermicompost or humic acid along with RDF for nutrient supply and as source of moisture conservation have resulted in higher values of, head diameter, oil content and 100 seed weight compared to sole application of $100 \%$ RDF. The two - year spring season data also revealed that the seed yield and oil content of sunflower was influenced significantly by the combined effect of moisture conservation and nutrient source. Though magnitude of soil moisture variation was small, all the hydrophilic substrates maintained higher soil moisture compared to use of RDF only. The results of two - year experiments indicated that adoption of moisture conservation techniques through use of polymer hydrogel and application of organics like FYM or vermicompost are proved to be suitable from the point of both moisture retention as well as source of nutrients for nutrient exhaustive crop like sunflower.
\end{abstract}

\section{Introduction}

Sunflower gained importance and popularity as a commercial oilseed crop of India under rainfed conditions since its introduction during the seventies as an oilseed crop to India. This is due to its suitability to many agro ecological regions, short duration, good quality oil and market price. This crop is mainly grown in spring season but can be grown in any season of the year since this crop is considered as day neutral plant because of its low photoperiod sensitivity. Karnataka is the leading sunflower producing state in the country and accounts for nearly $52 \%$ of the total area and $40 \%$ of the total 
production in the country. In India, sunflower is grown over an area of 5.20 lakh hectares with a production and productivity of 3.35 lakh tons and $643 \mathrm{~kg}$ per hectare, respectively during the year of 2015-16 (Anon, 2017). Though the crop has gained an important place among farmers, the productivity of sunflower is very low. The low productivity is mainly due to the crop growing under rainfed conditions on poor fertility soils with nonavailability of cultivars under moisture and nutrient stress situations. This crop is often considered as a soil nutrient depleting crop, which puts heavy demands on soil and applied nutrients (Thavaprakash et al., 2002). Due to its high uptake of nutrients sunflower responds very well to applied nutrients. Application of nutrients increased the seed yield of sunflower by $50 \%$ (Chorey and Thosar, 1997). The critical analysis of production factors to increase the productivity of sunflower under different agro ecological situations of India revealed that moisture and nutrient are the key inputs to realize higher and sustainable production of sunflower cultivars under rainfed conditions. The rainfed farmers are resource poor and identification of best agronomic practices suited to moisture and nutrient stress conditions are vital. Hydrophilic polymers like hydrogel have capability to store extra water in soil that enables crop to utilize the water over an extended period of time. Application of humic acid, fly ash and organic matter either through farmyard manure or vermicompost have been shown to increase CEC and improve soil texture and porosity leading to retention of higher soil moisture in the soil. FYM/ vermicompost in addition to moisture retention they act as nutrient sources also.

\section{Materials and Methods}

The field experiment was started during spring-2014-16 at Tirhut college of
Agriculture farm, Dholi, Dr. Rajendra Prasad Central Agricultural University, Pusa, Samastipur, Bihar (Formerly Rajendra Agricultural University, Pusa, Samastipur, Bihar). The experiment site was situated at $25^{\circ} 59^{\prime} \mathrm{N}$ latitude and $85^{\circ} 35^{\prime} \mathrm{E}$ longitudes with an altitude of $58.0 \mathrm{~m}$ above the mean sea level under humid sub tropical climatic zone which is greatly influenced by monsoon. The average annual rainfall is about $1163 \mathrm{~mm}$, out of which nearly $1026 \mathrm{~mm}$ is received during the monsoon extending from the middle of June to middle of October. The period between third weeks of December to first half of January receives occasional winter showers. January is the coldest month of the year with an average maximum and minimum temperature of 23.2 and $7.9{ }^{0} \mathrm{C}$, respectively. The soil was Calciorthent having $\mathrm{pH}$ 8.21, organic carbon $0.42 \%$, available N $196 \mathrm{~kg} / \mathrm{ha}$, $\mathrm{P}_{2} \mathrm{O}_{5} 14.8 \mathrm{~kg} / \mathrm{ha}$ and $\mathrm{K}_{2} \mathrm{O} 114.5 \mathrm{~kg} / \mathrm{ha}$. The experiment was laid out in Randomized Block Design (RBD), replicated thrice within a plot and involved 7 treatments. The crop was fertilized at the rate of $80 \mathrm{~kg} \mathrm{~N}, 90 \mathrm{~kg} \mathrm{P}_{2} \mathrm{O}_{5}$ and $40 \mathrm{~kg} \mathrm{~K} \mathrm{~K}_{2} \mathrm{O} / \mathrm{ha}$ in all the treatments. Nitrogen was applied through urea in two equal splits (sowing time, $30 \mathrm{DAS}$ ); $\mathrm{P}_{2} \mathrm{O}_{5}$ and $\mathrm{K}_{2} \mathrm{O}$ were applied as single basal dose in the form of di ammonium phosphate (DAP) and muriate of potash (MOP) along with one third dose of nitrogen at the time of crop sowing. The seeds of KBSH-44 cultivar of sunflower were sown by hand dibbed method with spacing of $60 \mathrm{~cm} \times 30 \mathrm{~cm}$. The potential sunflower hybrid, KBSH -44 was used with seven treatments viz., T1: RDF, T2: RDF $+5 t$ FYM/ha spreading across field, T3: RDF + 2.5t FYM/ha in seed furrows, T4: RDF + Hydrogel @ 2.5kg/ha in seed furrows, T5: $\mathrm{RDF}+$ Humic acid @ $2.5 \mathrm{~kg} / \mathrm{ha}$ in seed furrows, T6: RDF + Vermicompost @ 2.5t/ha in seed furrows and T7: RDF + Fly ash @ $2 \mathrm{t} / \mathrm{ha}$ in seed furrows. The observations were recorded on growth, yield attributes and yield. Costs and returns were computed based on the 
prevailing market price. The oil content of sunflower seed was estimated by using Nuclear Magnetic Resonance (NMR) method. The results were analyzed with suitable statistical procedures / method.

\section{Results and Discussion}

\section{Yield and yield attributes}

The data revealed that during spring seasons of 2016 and 2017 (pooled) application of $\mathrm{RDF}+2.5 \mathrm{t} \mathrm{FYM} / \mathrm{ha}$ in seed furrows(T3) resulted in highest head diameter $(15.76 \mathrm{~cm})$ followed by (T4) RDF + Hydrogel @ $2.5 \mathrm{~kg} / \mathrm{ha}$ in seed furrows $(15.38 \mathrm{~cm}),(\mathrm{T} 2)$ $\mathrm{RDF}+5 \mathrm{t} \mathrm{FYM} / \mathrm{ha}$ spreading across field $(15.34 \mathrm{~cm})$, (T6) RDF + Vermi compost @ $2.5 \mathrm{t} /$ ha in seed furrows $(14.66 \mathrm{~cm}),(\mathrm{T} 7) \mathrm{RDF}$ + Fly ash @ 2.0 t/ha in seed furrows (14.17 $\mathrm{cm})$, (T1) RDF $(14.15 \mathrm{~cm})$ and the lowest head diameter observed in (T5) RDF + Humic acid@2.5 kg/ha in seed furrows. (14.13cm). In the plant height RDF $+2.5 \mathrm{t} F Y M / h a$ in seed furrows(T3) resulted in highest in plant height $(178 \mathrm{~cm})$ followed by followed by (T4)RDF + Hydrogel @ 2.5kg/ha in seed furrows $(177 \mathrm{~cm}),(\mathrm{T} 2) \mathrm{RDF}+5 \mathrm{t} \mathrm{FYM} / \mathrm{ha}$ spreading across field (169 cm), (T1) RDF $(168 \mathrm{~cm}),(\mathrm{T} 7) \mathrm{RDF}+$ Fly ash @ 2.0 t/ha in seed furrows $(167 \mathrm{~cm})$, (T5) RDF + Humic acid@2.5 kg/ha in seed furrows (161), and the lowest in (T6)RDF + Vermi compost @ $2.5 \mathrm{t} / \mathrm{ha}$ in seed furrows. $(157 \mathrm{~cm})$. The results emphasize that application of FYM, hydrogel, vermicompost or humic acid along with RDF for nutrient supply and as source of moisture conservation have resulted in higher values of, head diameter, oil content and 100 seed weight compared to sole application of $100 \%$ RDF (T1). The two - year rainy season data (Table 1) also revealed that the seed yield and oil content of sunflower was influenced significantly by the combined effect of moisture conservation and nutrient source. The yield of the crop revealed that (T2) RDF + 5t FYM/ha spreading across field (1793 kg /ha) followed by (T7) RDF + Fly ash @ 2.0 t/ha in seed furrows (1765 kg/ha), (T3) RDF + $2.5 \mathrm{t} \mathrm{FYM/ha}$ in seed furrows $(1682 \mathrm{~kg} / \mathrm{ha})$, (T6) RDF + Vermi compost @ 2.5 t/ha in seed furrows. (1638 kg/ha), (T4) RDF + Hydrogel @ 2.5kg/ha in seed furrows $(1621 \mathrm{~kg} / \mathrm{ha})$, (T1) RDF (1553 kg /ha), and lowest in (T5) RDF + Humic acid @ $2.5 \mathrm{~kg} / \mathrm{ha}$ in seed furrows (1366 kg /ha), Significantly higher oil content was observed with $\mathrm{T} 3: \mathrm{RDF}+2.5 \mathrm{t}$ FYM/ha in seed furrows $(41.81 \%)$ followed by (T6) RDF + Vermi compost @ 2.5 t/ha in seed furrows. (41.72\%), and lowest observed in (T2) $\mathrm{RDF}+5 \mathrm{t} \mathrm{FYM} / \mathrm{ha}$ spreading across field $(40.95 \%)$. This might be due to rainfall occurred during flowering which has caused pollen wash thereby reducing the oil content. The data regarding oil yield found that (T2) $\mathrm{RDF}+5 \mathrm{t}$ FYM/ha spreading across field (733 $\mathrm{kg} / \mathrm{ha}$ ) followed by (T7) RDF + Fly ash @ $2.0 \mathrm{t} / \mathrm{ha}$ in seed furrows $(728 \mathrm{~kg} / \mathrm{ha})$ and lowest oil yield in (T5) RDF + Humic acid @ $2.5 \mathrm{~kg} / \mathrm{ha}$ in seed furrows $(565 \mathrm{~kg} / \mathrm{ha})$. In 100 seed weight data revealed that (T2) RDF $+5 \mathrm{t}$ FYM/ha spreading across field (4.94 g) followed by (T3) RDF + 2.5t FYM/ha in seed furrows (4.78 g) and the lowest in (T4) RDF + Hydrogel @ 2.5kg/ha in seed furrows (3.83 g).

\section{Economics}

The pooled data pertaining to the gross returns, net returns and $\mathrm{B}: \mathrm{C}$ Ratio. The highest gross returns in (T2) $\mathrm{RDF}+5 \mathrm{t}$ FYM/ha spreading across field (66490 Rs /ha) and lowest in (T5) RDF + Humic acid @ 2.5 $\mathrm{kg} / \mathrm{ha}$ in seed furrows (50642 Rs/ha). The highest net returns obtained in the (T2) RDF + 5t FYM/ha spreading across field (40575 Rs /ha) compared to other treatments and lowest net returns in (T5) RDF + Humic acid @ 2.5 $\mathrm{kg} / \mathrm{ha}$ in seed furrows(25547 Rs/ha). Similarly the highest $\mathrm{B}: \mathrm{C}$ ratio in (T2) $\mathrm{RDF}+5 \mathrm{t}$ FYM/ha spreading across field (1.57) followed by (T1) RDF (1.49). 
Table.1 Efficacy of hydrophilic polymer on Sunflower production in Dholi (2016- 2017, Pooled data)

\begin{tabular}{|c|c|c|c|c|c|c|c|c|c|c|}
\hline \multicolumn{2}{|c|}{ TREATMENTS } & \multirow{2}{*}{\begin{tabular}{|c|}
$\begin{array}{c}\text { Plant } \\
\text { height } \\
(\mathbf{c m})\end{array}$ \\
168 \\
\end{tabular}} & \multirow{2}{*}{\begin{tabular}{|c|}
$\begin{array}{c}\text { Head } \\
\text { diameter } \\
(\mathbf{c m})\end{array}$ \\
14.15
\end{tabular}} & \multirow{2}{*}{$\begin{array}{c}100 \\
\text { seed } \\
\text { wt. }(g)\end{array}$} & \multirow{2}{*}{\begin{tabular}{|c|}
$\begin{array}{c}\text { Seed } \\
\text { yield } \\
\text { (kg/ha) }\end{array}$ \\
1553 \\
\end{tabular}} & \multirow{2}{*}{$\begin{array}{c}\text { Oil } \\
\text { content } \\
(\%) \\
41.43\end{array}$} & \multirow{2}{*}{\begin{tabular}{|l|}
$\begin{array}{c}\text { Oil yield } \\
\text { (kg/ha) }\end{array}$ \\
643 \\
\end{tabular}} & \multirow{2}{*}{$\begin{array}{c}\begin{array}{c}\text { Gross } \\
\text { return } \\
\text { (Rs/ha) }\end{array} \\
57510 \\
\end{array}$} & \multirow{2}{*}{\begin{tabular}{|c|}
$\begin{array}{c}\text { Net } \\
\text { return } \\
\text { (Rs/ha) }\end{array}$ \\
34425 \\
\end{tabular}} & \multirow{2}{*}{$\begin{array}{l}\mathbf{B : C} \\
\text { ratio } \\
1.49 \\
\end{array}$} \\
\hline $\mathbf{T}_{1}$ & $\mathrm{RDF}$ & & & & & & & & & \\
\hline $\mathbf{T}_{2}$ & $\begin{array}{l}\mathrm{RDF}+5 \mathrm{t} \mathrm{FYM} / \mathrm{ha} \\
\text { spreading across } \\
\text { field. }\end{array}$ & 169 & 15.34 & 4.94 & 1793 & 40.95 & 733 & 66490 & 40575 & 1.57 \\
\hline $\mathbf{T}_{3}$ & $\begin{array}{l}\mathrm{RDF}+2.5 \mathrm{t} \\
\mathrm{FYM} / \mathrm{ha} \text { in seed of } \\
\text { furrows. }\end{array}$ & 178 & 15.76 & 4.78 & 1682 & 41.81 & 704 & 62366 & 36451 & 1.41 \\
\hline $\mathbf{T}_{4}$ & $\begin{array}{l}\text { RDF + Hydrogel } \\
@ 2.5 \mathrm{~kg} / \mathrm{ha} \text { in } \\
\text { seed furrows. }\end{array}$ & 177 & 15.38 & 3.83 & 1621 & 41.27 & 669 & 60057 & 32062 & 1.14 \\
\hline $\mathbf{T}_{5}$ & $\begin{array}{l}\text { RDF + Humic acid } \\
\text { @ } 2.5 \mathrm{~kg} / \mathrm{ha} \text { in } \\
\text { seed furrows. }\end{array}$ & 161 & 14.13 & 4.48 & 1366 & 41.45 & 565 & 50642 & 25547 & 1.02 \\
\hline $\mathbf{T}_{6}$ & 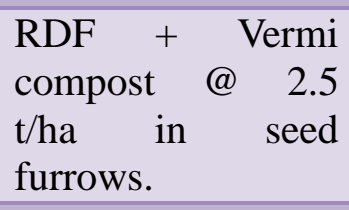 & 157 & 14.66 & 4.51 & 1638 & 41.72 & 683 & 60667 & 27332 & 0.82 \\
\hline $\mathbf{T}_{7}$ & $\begin{array}{l}\text { RDF + Fly ash @ } \\
2.0 \text { t/ha in seed } \\
\text { furrows. }\end{array}$ & 167 & 14.17 & 4.50 & 1765 & 41.23 & 728 & 65411 & 37621 & 1.35 \\
\hline \multicolumn{2}{|c|}{ SEm \pm} & 1.21 & 0.87 & 0.30 & 69.77 & 0.36 & 28.83 & 2600 & 2594 & 0.10 \\
\hline \multicolumn{2}{|c|}{$\mathrm{CD}(\mathrm{P}=\mathbf{0 . 0 5})$} & 3.77 & NS & NS & 217.22 & NS & 85.83 & 7763 & 8076 & 0.32 \\
\hline
\end{tabular}

The higher gross returns, net returns and B:C ratio of moisture conservation and nutrient sources might be due to higher seed yield coupled with higher market price.

In conclusion, the results of two-year experiment indicated that adoption of moisture conservation techniques through use of polymer hydrogel and application of organics like FYM or vermicompost are proved to be suitable from the point of both moisture retention as well as source of nutrients for nutrient exhaustive crop like sunflower. The higher quantities of soil moisture retained by the hydrophilic substrates provide extra available water to crops which facilitates better crop growth. More available water in the soil also means less frequent irrigation. Use of hydrophilic substrates helps in reducing the crop water requirements marginally and thus will address the adversities of climate change.

\section{References}

Annual Report 2015-16, ICAR-Indian Institute of Oilseeds Research, Hyderabad

Chorey, A.B. and Thosar, V.R. (1997) Effect of Individual Production Factors on Yield of Rabi Sunflower. PKV Res. J., 6 (21): 169-170. 
Ghutol, P.U., Soniya, C., Vilhekar., Godavari, S. Gaikwad., Thakare, G.V., Mane, P.N. and Sakhare, S.B. 2018. Efficacy of Hydrophilic polymer Hydrogel and Water Retentive material on Growth and yield of Sunflower (Helianthus annus L.) International Journal of Current Microbiology and Applied Science, Special issue-6: 2984-2990.

Gaikwad, Godavari S., Vilhekar, Soniya C., Mane, P. N. and Vaidya, E. R. (2017). Impact of organic manures and hydrophilic polymer hydrogel on conservation of moisture and sunflower production under rainfed condition. Adv. Res. J. Crop Improv., 8 (1): 31-35, Kazem, S.N., NabaviKalat, S.M. and Sadrabadi Haghighi, R. (2013) The Study on Effects of Bio-fertilizer and
Foliar Spray with Complete Fertilizer on Yield and Yield Components of Sunflower (Helianthus annuus L.). Inter. J. Agron. And Pl. Prod., 4(12): 3404-3409.

Reddy, B.N., Chandranath, H.T., Lokesha, K.R. and Muralidharudu, Y. (2003) Effect of Nutrients and Moisture Conservation Practices on Growth, Yield and Economics of Rabi Sunflower under Rainfed Vertisols. $J$. Oilseeds Res., 20(2): 244-248.

Thavaprakash, N., Sivakumar, S.D., Raja, K. and SenthilKumar, G. (2002) Effect of Nitrogen and Phosphorus Levels and Ratios on Seed Yield and Nutrient Uptake of Sunflower Hybrid DSH-1. Helia, 25(37): 59-68.

\section{How to cite this article:}

Vikram Bharati, S. Kiran Kumar and Prasad, S.S. 2019. Efficacy of Hydrophilic Polymer on Sunflower (Helianthus annus L.) Production in Spring. Int.J.Curr.Microbiol.App.Sci. 8(05): 1705-1709. doi: https://doi.org/10.20546/ijcmas.2019.805.197 